\title{
School As A Social System
}

\section{Kıvanç BOZKUŞ*}

\begin{abstract}
Social system perspective which belongs to systems theory has been elaborated comprehensively using its founders' ideas, and characteristics of schools have been explained consulting to this perspective. The course of social system idea has been reviewed along with its relation to other systems. How researchers who assumes schools as social systems define the main components of the school has been reviewed. By attaching importance to the humane side of school, social systems perspective differentiates school from for profit organizations. For this reason, social systems theory has been one of the most realistic models for schools. The assumptions behind this assertion are examined. It is probable that this perspective sheds light on research conducted in educational organizations.
\end{abstract}

Key Words: Social systems, systems theory, schools.

\section{Özet}

\section{Bir Sosyal Sistem Olarak Okul}

Sistemler kuramına ait olan sosyal sistem görüşü, kurucularının fikirlerinden yararlanılarak kapsamlı biçimde ele alınmış ve bu kuram ile okulların özellikleri açıklanmıştır. Sosyal sistem fikrinin gelişim süreci, diğer sistemlerle olan ilişkisiyle birlikte incelenmiştir. Okulları sosyal sistemler olarak ele alan araştırmacıların, okulun temel parçalarını nasıl tanımladıkları da ele alınmıştır. Sosyal sistem görüşü okulun insani yönüne dikkat çekerek okulu kar amaçlı kurumlardan ayrı tutmuştur. Bu nedenle sosyal sistemler kuramı okulları en gerçekçi açıklayabilen modellerden birisi olagelmiştir. Bu savın arkasındaki varsayımlar incelenmiştir. Bu görüşün eğitim kurumlarında yürütülen araştırmalara ışık tutması mümkün görülmektedir.

Anahtar Kelimeler: Sosyal sistemler, sistemler teorisi, okullar.

\footnotetext{
* Arş. Gör., Artvin Çoruh Üniversitesi, kbozkus@artvin.edu.tr
} 


\section{INTRODUCTION}

Schools are important organizations that prepare our children for adult roles. Their working mechanism has a strong effect on the quality of education. There are many theories that try to explain the nature of the school organizations. Among them, social systems theory has been one of the most realistic models for schools. This paper examines the assumptions behind this assertion and tries to find out the characteristics of schools that can be explained or interpreted using social systems theory.

Talcott Parsons was the first formulator of Social systems. They are based on interpersonal relationships regardless of their size and complexity, and they consists of individual actors interacting in a culturally structured system full of shared symbols (Parsons, 1951). Social systems have three basic characteristics called the interdependence of the parts, their organization into some sort of whole, and the intrinsic presence of both individuals and institutions (Getzels, Lipham \& Campbell, 1968).

After the Second World War, schools were considered as formal organizations that are structured to accomplish organizational goals. Organizational behavior was assumed to be rational and consisted of rational interactions of individuals. However, schools' goals and activities were not linked with clear lines of communication, so people within schools were not acting to achieve collective goals which are essential in rational systems. Apparently, schools had resemblance to natural systems which contain groups that work to achieve not only organizational goals but also their own goals.

Schools had features of both rational and natural systems and also have strong relationships with their external environment that stems from the dependence on resources and accoun- tability. For this reason, school systems were associated with open systems perspective which is considered an integration of both former systems (Hoy \& Miskel, 2005). Besides organizational roles, behaviors of individuals were also ruled by personal needs.

Researchers needed to explain how schools work under a more comprehensive model called social systems theory. Parsons, Getzels, Guba, Lipham, Campbell, Hoy and Miskel were the leading researchers that adapted this theory to schools. This theory inherits key concepts from its predecessors. Therefore, we should explore rational, natural, and open systems theories in order to understand social systems.

The purpose of this paper is twofold: (a) to elaborate social systems theory and (b) to investigate how scholars who accept schools as social systems define basic characteristics of schools and relate them with the theory, or to learn how they visualize schools as social systems.

\section{Systems Theory}

Scholars have developed various perspectives under the systems theory to analyze organizations through different lenses. In this section, perspectives of rational systems, natural systems, open systems and social systems will be elaborated.

\section{Rational systems}

Rational systems perspective views organizations as machines built to achieve some desired ends. Their main purpose is to mold every aspect of an organization specifically in respect to a proven prescription in order to ensure its working in a solid and stable fashion. By utilizing what already is known to be working, any risk of failure and emergence of undesired outcomes are eliminated. The assumption is 
that if everything stays within the lines of logic, so will the outcomes.

\section{Goals}

Organizations are formed for a main purpose: to accomplish goals. Goals specify the outcomes to be achieved through organizational activities. The nature of activities and the organizational structure to carry out activities depend on the specificity of the goals. Less specificity makes it harder to design a structure while allowing choosing among various activities. However, "vague goals do not provide a solid basis for formal organizations. Either the goals become more specific and limited over time... or the structures developed are likely to be unstable and amorphous" (Scott, 1998, p. 35).

\section{Formal organization}

Formalization derives from the bureaucratic structure of rational systems. Within rational systems there are hierarchies of authority, division of labor, work specialization, rules and regulations. All these are typically associated with bureaucracy. Organizational goals require obedience to clear rules which leave little room for interpretation. Obedience is enforced through rewards and sanctions.

Individuals within organizations are assigned to specific roles that are independent of their personality. The goal here is to make behavior predictable by standardizing roles (Scott, 1998). So, each person does exactly what s/he is prescribed to do and produces only the desired outcomes that are essential to working of the organization. This resembles to a machine. Each part does its job and the machine works in a linear fashion. However, human beings are not as simple as the parts of a machine and they cannot be expected to be always rational and work like robots. This assumption was later defended by advocates of natural systems.

\section{Natural Systems}

While rational systems emphasize goals, natural systems propose that organizations, in fact, strive to survive and the goals are meaningful as long as they help the organization's survival. Therefore, the organization may modify or even remove the goals when necessary. Organizations are living systems consist of social elements and therefore cannot be used as tools and thrown away when the goals are accomplished. They tend to exist even after there remain no more goals to achieve (Gouldner, 1959). Natural systems emphasize the human side of organizations, and they reject the dualism that splits people and organizations (Greenfield \& Ribbins, 1993).

\section{Informal organization}

Individuals have to interact with each other to carry out organizational goals. They learn each other's personal life, habits, feelings etc. Some people are liked and respected while others are not. Those who are followed have an informal authority over others. Those who are disliked may be alienated. Also, when personal interests differ from those of organizations, informal structures are more likely to occur. Research shows that within each formal organization, informal structures occur inevitably (Hoy \& Miskel, 2005).

Although informal organization is first emphasized by natural systems theory, it should not be conceived of unique to natural systems. While being a formal organization, social systems too are to some extent informal organizations. To understand a social system as a whole, one should look at both formal and informal organizations within it. Social systems cannot survive without an informal organization that allows "maintenance of group cohesion through regulating the willingness to serve 
and the stability of objective authority" (Getzels, Lipham \& Campbell, 1968, p. 42).

\section{Individual needs and social behavior}

Getzels and Guba (1957) define the administrative process as strongly related to social behavior of individuals within organizations. They propose a social system theory for settings with a hierarchy of relationships. Two components of their theory are institutions and individuals. Each of them has two sub-components. Institutional roles and role expectations constitute the nomothetic, and individual personality and need-dispositions constitute the idiographic dimension of social behavior. The authors articulate characteristics of institutions and individuals. Institutions have purposes to meet specific ends, have people to achieve purposes, have organizational structure which assigns roles to people and makes rules to achieve purposes, have norms that are represented as roles that impose specific behavior on individuals, are sanction-bearing which means applying positive and negative sanctions to make sure that norms are conformed. Roles prescribe the behavior of individuals. They refer to positional authority, complement each other, and adhere to role expectations defined by the institution. Personality is a combination of need dispositions that direct a person to accomplish a desired end.

In short, Getzels and Guba (1957) define social behavior as a result of the interaction between role and personality. The amounts of contributions of these two factors vary according to persons and actions, but never only one of them rules the behavior. One can act according to the role more than personality while another individual's behavior is affected mostly by personality. For the authors, the administration process in social systems is nothing but understanding why organizational behavior cannot be associated with only either role or personality.

\section{Open Systems}

Open systems theory was developed as a reaction to former rational and natural system theories that described schools as independent of their external environment. Open systems are affected from outer forces while being simultaneously dependent on them. Their boundaries are broader than those of classical closed school systems, and hard to identify clearly. The main element that distinguishes open systems from the others is the transformation process. It is the process of raw materials (inputs) into products (outputs). In an educational setting (e.g. school), inputs can be considered as pupils and outputs as graduates. Therefore, the system continuously takes sources from its environment and then transforms them according to the environment's needs. An important element of this interaction called feedback, information about the quality of the process, lets the system correct and enhance itself. 
ENVIRONMENT

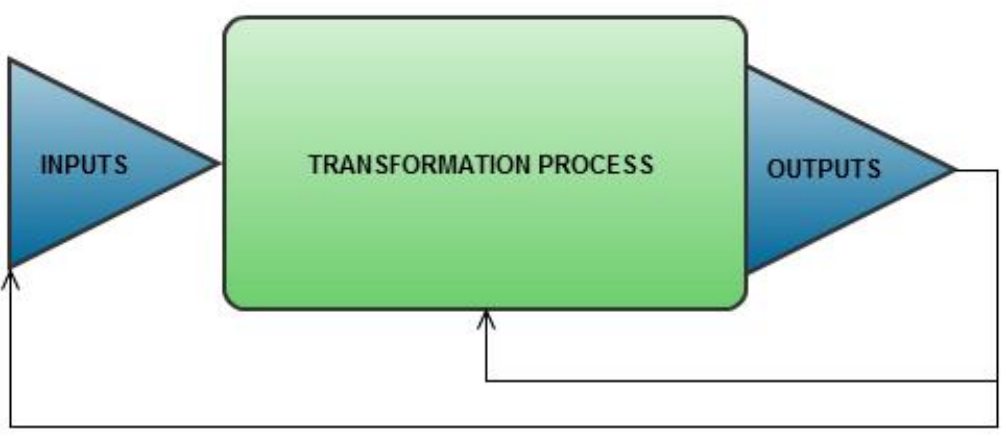

FEEDBACK

Figure 1. Schematization of open systems.

Early theorists of social systems identified them as closed systems (Getzels \& Guba, 1957; Luhmann, 1995). That perspective did not work for schools as they are strongly interrelated to their environment. Schools are dependent on external sources by nature. In a simplistic sense, they need funds and children from the outside of their boundaries. They are accountable for producing ends that are not specified by themselves but by their communities. By acknowledging these realities, Hoy and Miskel (2005) assert that social systems are, at the same time, open systems.

\section{Loose Coupling}

Research reveals that connections between rules and behaviors and among structural units may not consist of solid lines, and schools have little coordination within the subsystems of the organization, a situation known as loose coupling. Glassman (1973) was one of the first researchers who used the term, and he asserts that "the degree of coupling, or interaction, between two systems depends on the activity of the variables which they share" (p. 84). Thus, if there are few variables to be shared between systems then they are independent of each other. Weick (1976) adapts this to schools by remarking that "...if we did not find many variables in the teacher's world to be shared in the world of a principal and/or if the variables held in common were unimportant relative to the other variables, then the principal can be regarded as being loosely coupled with the teacher" (p.3).

Regarding to the amount of autonomy that subsystems have, the school structure can be described as loosely or tightly coupled. Since never a single form of coupling suits well to every situation, leaders should exercise both forms as needed (Kowalski, 2010). Open systems tend to be loosely coupled. Scott (1998) explains this by stating that "one of the main contributions of the open system perspective is the recognition that many systems-especially social systems-contain elements that are only weakly connected to other elements and that are capable of fairly autonomous actions" (p.88). As a result, teachers got freedom in their classroom activities under weak administration scrutiny. This is useful because teachers are experts of instruction while principals are skilled at administration. Thus, teachers can make use of their expertise if they are not disrupted by the administration. Some researchers supported teachers' freedom and little accountability for their professional activities to let them utilize various student abilities (Dellar, 1994). Other than teacher autonomy, loosely coupled structures of schools increase decentralization and adaptation (Weick, 1976). Tight 
coupling is a result of rationalization. Therefore, schools that are less rational systems tend to be loosely coupled.

\section{Social Systems}

To understand social systems, it is helpful to delve into the main characteristics that asserted by researchers contributing to the development of this theory. Hoy and Miskel (2005) bring together the assumptions of various researchers and incorporate them into educational settings. Many researchers assert that social systems are peopled, goal oriented, structural, normative, sanction bearing, political, and open systems.
These assumptions help us grasp the common characteristics of social systems. These characteristics are elaborated under related sections of this paper.

Hoy and Miskel (2005) visualize the elements of social systems. Their model resembles Getzel and Guba's (1957) open systems model. However, they incorporate their own perspective of social systems by blending rational and natural systems models. They inject four sub-systems into the transformation process. Each subsystem will be elaborated according to their view.

ENVIRONMENT

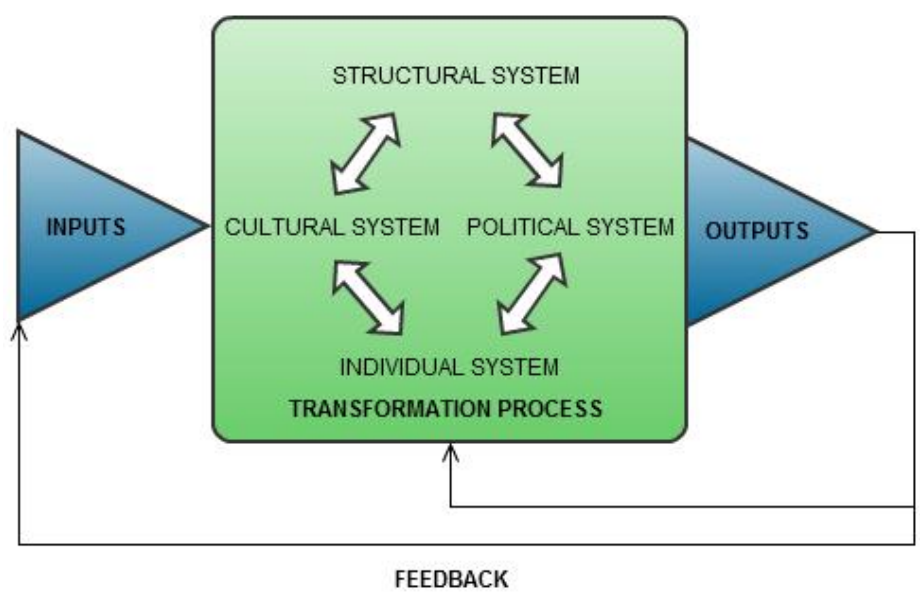

Figure 2. The elements of social systems (Hoy \& Miskel, 2005, p. 31).

\section{Structural system}

The structural system is similar to those of formal organizations. Bureaucratic expectations rule organizational behavior. Roles that are derived from those expectations are represented by positions in a hierarchy. The hierarchy distributes tasks to specialized individuals, and the Organization is a result of the division of labor (Parsons, 1960). The structure of social systems inherits many elements from rational, natural and open systems theories. For example, social systems have both formal and informal organizations within them.

\section{Cultural system}

Similar to the emergence of informal organizations, culture emerges from interactions of individuals within a system. As individuals interact, they share values, beliefs, habits and gain an identity as a group. This is a natural outcome of all social systems. Culture is the most visible aspect of the organizational life that distinguishes it from others. Culture significantly affects behavior through establishing commitment to shared norms among individuals. In other words, culture represents the unwritten, feeling part that is the set of values, 
norms and beliefs of the organization (Daft, 2009).

Hofstede (1991) defines culture as "the collective programming" of the members of an organization (p. 262). They have attitudes which stimulate them to act on a favorable fashion (Rokeach, 1972). It can be said that attitude governs one's mind while culture governs the organizational mind. Therefore, each member's attitudes gathered in a pool called culture.

\section{Individual system}

Each individual has a different set of needs and beliefs that affect behavior. Unlike organizational expectations, individual needs and expectations are flexible and adaptable to formal roles, and thus they provide a room for discretion in behavior. Individuals interpret their roles according to their behavior. Confirming Getzel and Guba's (1957) idea, Hoy and Miskel (2005) claim that social behavior is formed by the interaction of bureaucratic expectations and individual needs. Along with behavior, individual needs and beliefs also form feelings. Social systems have strong links with "the attitudes, perceptions, beliefs, motivations, habits, and expectations of human beings" (Katz \& Kahn, 1978, p. 37). Since people are an important element of social systems, their positive feelings toward the organization significantly affect the overall health of the system.

\section{Political system}

Politics inevitably appear in organizations (Senge, 1990). Politics emerges from the interaction of authority and power within an organization. There are three sources of power in an organization. Formal power originates from the structural system, the cultural system produces informal power, and individuals have the power of expertise. Politics is the way of how some individuals use their influence for their interests. They often use their power at backstage to profit their private affairs at the expense of the organization. It is illegitimate because it is not stemmed from any formal authority, therefore it does not have to be in accordance with accepted standards of the organization. Hence, it is immune to the sanctions of formal authority. Also, from the social behavior perspective, politics utilizes the absolute use of individualistic needs, and thus ignores the organizational role expectations. Consequently, it benefits individual interests only. However, this does not mean that politics is always harmful to the organization. Mintzberg (1983) claims that politics can provide the organization with many advantages. One advantage of the political system is that it forces a school to be responsible to its environment. Schools must pay attention to external pressures, respond to their demands, and produce outcomes. In other words, schools are compelled to be open systems by political forces. Actually, the political system is in strong relation with the open system, and share many similarities. It is clear that politics is informal and illegitimate, yet an inevitable factor affecting organizational behavior (Hoy \& Miskel, 2005).

\section{Characteristics of Schools}

In this section, some characteristics of schools including structure, culture, climate, leadership, decision making and relationships among personnel will be elaborated from the perspective of the social systems theory.

\section{Structure}

As social systems, schools' structures have characteristics of rational, natural, and open systems. They have hierarchies of authority, goals, and role expectations similar to bureaucratic organizations. Individual needs affect employee behavior, organizational goals are not firm, informal organizations derive from interactions among individuals, and schools 
have to interact with their environment. Kowalski (2010) asserts that schools are social systems and have three qualities: arbitrary and consequential boundaries, interrelated subsystems, and multiple causation- events happen as a consequence of more than one cause.

Schools are staffed by professionals, so they have some disadvantages of professionalism such as unions' striving to limit principals' control over teachers, uneven distribution of pay, teachers' lack of skills in professionalism (Dornbusch \& Glasgow, 1996). As open systems, schools have relationships with external agencies like unions. Exertion of political power and authority between schools and the agencies becomes an element of the school structure.

Schools are institutional organizations whose structures are formed by societal rules and beliefs, so an emphasis on how schools response to those rules and beliefs becomes a main aspect to explain and evaluate their structures (Dornbusch \& Glasgow, 1996). School as an institution is "a natural product of social needs and pressures" (Selznick, 1957, p. 5). This too proves that schools are open systems that are dependent on and affected by their environment. For example, in low socio economic status communities, parents often do not demand high academic quality from schools. Because of this weak external pressure, schools in those communities expect less performance from students and have low standards (Dornbusch \& Glasgow, 1996).

Ben-Baruch (1983) asserts that schools have six basic traits. They are people-processing organizations, goal oriented, structural, and consist of processes, communication and decision making activities. The structure of social organizations is related to relationships of professionals within the organizations. Thus, the structure is closely aligned with the nature of interactions and it is affected by working styles of people.
For instance, since teachers work alone instead of in teams, the structure of schools tends to be hierarchically flat because it has few hierarchical levels (Ben-Baruch, 1983). However, creating work groups and freeing them from intense supervision let teachers be more creative and responsible for teaching (Kinsler \& Gamble, 2001).

When a bureaucratic organization relies heavily on sanctions to ensure performance and obedience of staff, a process called "decadence of the hierarchy" becomes inevitable (BenBaruch, 1983, p. 112). Individuals who fear their superiors tend to be safe by selecting subordinates who are less competent than they should be. This leaves the lower ranks of the hierarchy staffed by unskilled people. To avoid this, recruitment of superintendents and principals should be done by the community (BenBaruch, 1983).

Schools in decentralized education systems that allow them to be locally involved in social needs of people around them are more likely to be open and social systems. Community members have an impact on educational decisions made in schools. Schools are obliged to produce outcomes that are desirable by their environments. To please parents, schools must continuously interact with them to learn their needs and to get feedback on educational processes. Since education is complicated and not routine, schools can perform better with a decentralized structure (Bolman \& Deal, 1984). On the other hand, in centralized educational systems, environmental pressures are directed to departments of education, and thus schools are completely responsible to the department. This results in a formation of a pyramidal hierarchy that limits community intervention. However, in decentralized systems, hierarchy is flat, so schools are in direct interaction with their communities. 


\section{Culture and Climate}

Distinguishing culture from the climate is a difficult one and vice versa. They share many things in common, but still there are differences between them "whereas climate is about feelings and behavior, culture is more focused on values, beliefs, and assumptions underlying feelings and behavior..." (Kowalski, 2010, p. 43).

Climate represents an organization's distinguishing characteristics, feeling and behavior that can be presented with a framework which consists of four elements: physical frame is the physical factors of a school like equipment, classrooms etc., social frame is the social environment mostly related to social behavior of individuals within a school, structural frame represents factors such as hierarchy, authority, role, and symbolic frame is the parts of culture like believes, norms, values (Kowalski, 2010).

Kowalski (2010) categorizes school climate according to disposition to interactions. He categorizes interactions as internal and external. Internal interactions consist of interactions among teachers, and between teachers and the principal while external interactions consist of interactions with parents and other stakeholders outside the school. He puts both internal and external interactions on the same continuum. Therefore, individuals in schools that have open climates have to interact with other individuals from both inside and outside of the school. However, this can be generalized to open systems only. A school that is closed to its external environment may have a great amount of interactions among individuals inside the building. Therefore, we can assume that the author already considers schools as open social systems.

School culture is preserved and transferred to new members by the socialization process
(Kowalski, 2010). New teachers learn shared values, beliefs and norms when they interact and build relationships with their colleagues. During conversations, they are informally taught ways of accepted behavior. This brings us back to the natural systems theory which admits informal socialization among individuals within an organization.

\section{Leadership and Decision Making}

In social systems of schools an important aspect of leadership is the quality and systematic effects of functions and behaviors of principals as leaders. Principals' behaviors can be inspected under social systems theory. In many schools, principals' social behavior surrounds all other individuals and processes from decision making to the evaluation of organizational efficiency.

Kowalski (2010) offers school improvement through decision making as the main focus of school leadership. However, there may be times when teachers do not agree and follow. The functional perspective of Getzels, Lipham and Campbell's (1968) administrative process may shed light on these situations. Functions are considered as the allocation of roles and facilities. Therefore, principals should revise the functions of administrative processes.

Leaders in similar social systems exhibit divergent behavior which is associated with organizational role and personality (Getzels \& Guba, 1957; Kowalski, 2010). Kowalski (2010) explains why school principals even in the same districts behave differently. He extends Getzels and Guba's (1957) social behavior theory by adding a new dimension called work context. Formal role expectations and personal facets are the dimensions inherited from the social behavior theory. Work context consists of culture and politics within and around (e.g. community) schools. His assertion is based on open systems 
theory and is an attempt to conceive of social systems as open systems opposing to Getzels and Guba's (1957) closed social systems perspective. Therefore, he implies that schools interact with their environments, and they are under the influence of outer forces just like any other open and social system. Principals' leadership is influenced by cultural standards and political forces even when they are inconsistent with the principal's formal role expectations and personal facets. For example, a principal who expresses his ideas about sex education which are incongruent with the local values may be chastised by the local community and be given a formal warning by the superintendent.

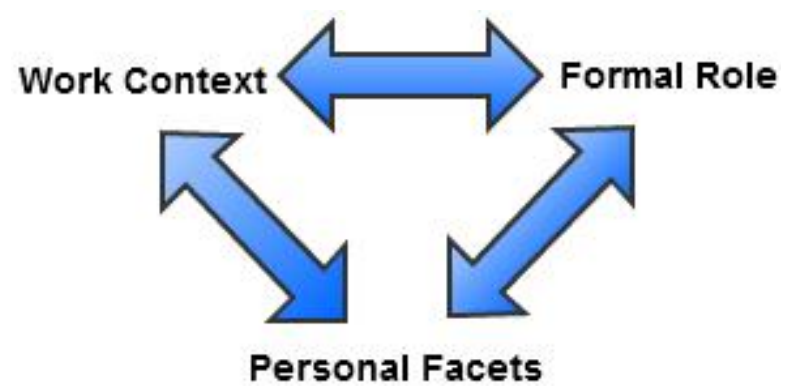

Figure 3. Principal behavior (Kowalski, 2010, p. 52)

Individuals and organizations try to impose their motives on each other. The process done by the organization is called the socializing process, and the personalizing process when it is done by the individual. Problems occur if there is discordance between the two processes. Therefore, leaders should seek harmony between them (Getzels, Lipham \& Campbell, 1968). In addition, there are two views about the ownership of leadership. One view asserts that an individual who has the greatest influence and leadership capabilities is the leader of a group. The other view claims that leadership naturally occurs and shared within a social group. Therefore, leadership belongs to the group instead of a single individual (Hoy \& Miskel, 2005). The shared leadership aspect of the second view is related to the distributed leadership framework. Spillane and Healey (2010) assert that individuals without any formal leadership designation can be leaders too. Therefore, even teachers and students may take responsibility for leadership roles.

\section{Relationships}

Social organizations like schools are stemmed from interaction among people both within and outside of the organization. Relationships within school building and with the community are essential elements of socialization and have a significant impact on many vital processes. Building and maintaining relationships can be considered as a process by which principals and teachers link learning that occurs inside and outside of the building (Kowalski, 2010). Since the social behavior forms those interactions, its perspective can be useful to some extent in analyzing relationships. For example, problems may occur when roles and personality conflict (Getzels, Lipham \& Campbell, 1968). Compatibility of personality with organizational roles is so important that administrators must consider it from the beginning of staff relationships that is the recruitment. It is wise to hire people who fit best to the school's goals to maintain smooth relationships and educational operations. However, given the complexity of personality, some incompatibilities are inevitable, so people who can tolerate them and 
make compromises would be targeted when hiring (Getzels, Lipham \& Campbell, 1968).

In some large educational settings, the recruitment process is standardized and strongly aligned with organizational needs neglecting personal aspects. Protesting this notion, Getzels, Lipham and Campbell (1968) propose a model for the recruitment of new personnel. People are very important. Social organizations are peopled and every action is carried out by them. Their needs should be taken into consideration when choosing their future peers. After all, the new staff will interact with them more than with their administrators. Therefore, the prospective staff should be informed of personality requirements for the job and encouraged to interact with the already-employed staff before the recruitment to learn informally how the school works. Otherwise problems resulting from conflicts between roles and personalities may occur.

Their model makes sense from the point of social systems, but it is hard to implement in centralized educational settings in where people are hired through standardized processes due to the vast amount of prospects entering into the profession each year. Especially in the countries where principals have no power to hire teachers and other staff, the recruitment is carried out by the departments of education, so this model has limited applicability in those countries. To avoid problems resulting from role-personality conflicts, the authors suggest that administrators should clarify role expectations and increase two-way communication opportunities within schools. After hiring people whose personalities let them adapt to their roles, administrators must clarify the roles in detail by engaging new staff in two-way communication that requires letting them express their feedback. Otherwise, administrators cannot feel certain that they are understood. Two-way communication is also important in daily organizational life. To overcome problems caused by lack of communication, the authors suggest dividing the organization into subunits, so the staff may find more opportunity for face to face conversations. The division of labor and work specialization plays a role here.

\section{Conclusions}

Social systems theory has been a sound perspective to explain the working of schools. It offered scholars to consider the many aspects of school organizations which are full of social beings. Schools are different from for profit organizations, for they produce public service instead of goods. Mechanistic views fail to focus on human relations side of educational settings. Therefore it is more rational to think schools through the lens of social systems theory. Vast amount of research are carried out to investigate teachers', administrators', students' and parents' perceptions of many variables mostly related to interactions among those people in schools. Social systems perspective can set the stage for constructing a background and rationale for those research.

\section{References}

Ben-Baruch, E. (1983). Schools as social systems. Beersheba: Ben Gurion University.

Bolman, L. G., \& Deal, T. E. (1984). Modern approaches to understanding and managing organizations. San Francisco: Jossey-Bass.

Campbell, R. F., Cunningham, L. L., Nystrand, R. O., \& Usdan, M. D. (1990). The organization and control of American schools. New York: Macmillan.

Daft, R. L. (2009). Organization theory and design. (10 ed.). Mason: South-Western College Publishing. 
Dellar, G. B. (1994). Schools as open social systems: A study of site specific restructuring. Paper presented at the Annual Meeting of the American Educational Research Association. New Orleans, LA, April 4-8, 1994.

Dornbusch, S. M., \& Glasgow, K. L. (1996). The social structures of schooling. Annual Review of Psycholo$g y, 47(1), 401$.

Getzels, J. W., \& Guba, E. G. (1957). Social behavior and the administrative process. The School Review, 65(4), 423-441.

Getzels, J. W., Lipham, J. M. \& Campbell, R. F. (1968). Educational administration as a social process. New York, Harper \& Row.

Glassman, R. B. (1973). Persistence and loose coupling in living systems. Behavioral Science, 18, 83-98.

Gouldner, A. W. (1959). Organizational analysis. In R. K. Merton (Ed.). Sociology today (pp. 400-428). New York: Basic Books. (As cited by Scott, 1998).

Greenfield, T., \& Ribbins, P. (1993). Greenfield on educational administration. London: Routledge.

Hofstede, G. (1991). Cultures and organizations: software of the mind. London: McGraw-Hill UK.

Hoy, W. K., \& Miskel, C.G. (2005). Educational administration. (7 ed.). New York: McGraw-Hill.

Katz, D., \& Kahn, R. L. (1978). The social psychology of organizations (2 ed.). New York: John Wiley \& Sons.

Kinsler, K., \& Gamble, M. (2001). Reforming schools. New York: Continuum.

Kowalski, T. J. (2010). The school principal: Visionary leadership and competent management. New York: Routledge.

Luhmann, N. (1995), Social systems. Stanford: Stanford University Press.

Mintzberg, H. (1983). Power in and around organizations. Englewood Cliffs: Prentice Hall.

Parsons, T. (1951). The social system. New York: Free Press.

Parsons, T. (1958). Some ingredients of a general theory of formal organization. In A.W. Halpin (Ed.). Administrative theory in education. Chicago: University of Chicago. (As cited by Getzels, Lipham, \& Campbell, 1968).

Parsons, T. (1960). Structure and process in modern societies. New York: Free Press.

Rokeach, M. (1972). Beliefs, attitudes, and values. San Francisco: Jossey-Bass.

Scott, W. R. (1998). Organizations. (4 ed.). New Jersey: Prentice Hall.

Selznick, P. (1957). Leadership in administration. New York: Harper \& Row.

Senge, P. M. (1990). The fifth discipline. New York: Doubleday.

Spillane, J. P., \& Healey, K. (2010). Conceptualizing school leadership and management from a distributed perspective. The Elementary School Journal, 111(2), 253-281.

Weick, K. E. (1976). Educational organizations as loosely coupled systems. Administrative Science Quarterly, 21(1), 1-19. 


\section{Genişletilmiş Özet}

Okullar çocuklarımızı yetişkin rollerine hazırlayan önemli kurumlardır. Çalışma mekanizmalarının eğitimin niteliği üzerinde kuvvetli bir etkisi vardır. Okul örgütlerinin doğasını açıklamaya çalışan birçok teori bulunmaktadır. Sosyal sistemler teorisi ise okulları en gerçekçi açıklayabilen modellerden birisi olagelmiştir. Çalışma bu savın arkasındaki varsayımları incelemiş ve okulların bu teori ile yorumlanabilen özelliklerini açıklamaya çalışmıştır.

Parsons'a göre sosyal sistemler büyüklükleri ne olursa olsun paylaşılan simgelerle dolu bir kültürel yapı içerisinde etkileşen kişilerin arasındaki ilişkilere dayanmaktadır. Okulların başta, diğer örgütlerde olduğu gibi amaçlara dayalı biçimsel yapılar olduğu düşünülmekteydi. Örgütsel davranışın rasyonel olduğu ve kişilerin amaçlı etkileşiminden kaynaklandığı varsayılmıştı. Hâlbuki okulun hedef ve faaliyetleri belirgin iletişim kanallarıyla bağlantılı değildi ve dolayısıyla insanlar ortak bir amaca ulaşmaya çalışmıyorlardı. Görünüşe göre okullar, sadece örgütün amaçlarına değil aynı zamanda kendi amaçlarına da ulaşmaya çalışan gruplardan oluşan doğal sistemlere benzemekteydi. Okullar hem rasyonel hem de doğal sistemlerin özelliklerine sahipti ve ayrıca çevreleriyle kaynak ihtiyacından ve hesap verebilirlikten kaynaklanan güçlü ilişkileri vardı. Bu sebeple okullar, önceki sistemleri bütünleştiren açık sistemlerle ilişkilendirildi. Örgütsel rollerin yanında, bireylerin davranışlarını kişisel ihtiyaçlar da şekillendirmekteydi. Araştırmacılar okulun nasıl çalıştığını açıklamak için daha kapsamlı bir modele, sosyal sistemler kuramına ihtiyaç duydular. Parsons, Getzels, Guba, Lipham, Campbell, Hoy ve Miskel bu kuramı okullara uyarlayan önde gelen araştırmacılardır.

Kendinden önceki kuramların bazı özelliklerini taşıdığı için çalışmada sistem kuramı altında şekillenen görüşlere yer verilmiştir. Çalışma sosyal sistem kuramını incelemiş ve okulları birer sosyal sistem olarak ele alan araştırmacıların okulun özelliklerini nasıl tanımladıkları da irdelenmiştir. Eğitim kurumlarında yürütülen araştırmalarda sosyal sistem kuramının iyi bir zemin oluşturabileceği çıkarımında bulunulmuştur. 